\title{
Assessing Customers' Attitudes/Expectations Toward Online Grocery Businesses
}

Yoon C. Cho, KDI School of Public Policy and Management, Korea

\begin{abstract}
Customer attitudes toward online purchasing behavior have relied on various factors, such as product category, price, and brand name awareness of the store. Customer attitudes toward online shopping are also greatly affected by the inherent limitation of virtual shopping: quality is not easily judged on the Web, particularly for products which the Web cannot deliver sensory experiences. The purpose of this study is to examine customer attitudes toward an online store that sells "look-and-feel" products with various qualities" that appear to grow and receive increased attention. In particular, the author investigated i) the factors affecting customer attitudes toward the online grocery store; ii) how those factors affected the perceived ease of use (EOU) and usefulness (U); and iii) the effects of the perceived ease of use (EOU) and usefulness $(U)$ on overall expected customer satisfaction toward the online grocery store. Surveys were conducted and the major findings suggest that customers' purchase decisions in the electronic marketplace are affected by how online stores apply strategies to maximize customer satisfaction. Furthermore, this study provides managerial implications and offers suggestions for e-businesses.
\end{abstract}

Keywords: E-Commerce, E-Satisfaction, Ease of Use, Usefulness, E-commerce CRM.

\section{INTRODUCTION}

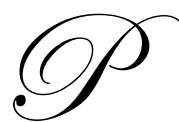

revious studies have examined various factors that affect the success of online businesses. Among the factors that affect the success of e-business, "product category" (i.e., product feature) has been addressed as an important factor that affects online customers' purchasing behavior. Product category has played an important role in classifying traditional marketing strategies. In the offline environment, products (particularly consumer-goods) have been classified based on risk (e.g., price) and effort (i.e., purchasing effort due to amount of time spent before decision making, convenient location, etc.). In the online environment, products have been classified by considering risk and uncertainty due to the inherent limitations of e-businesses (i.e., product quality is delivered via Computer-Mediated Communication (CMC) system: see Figure 1). Figuiredo's (2000) dot com retail continuum (Figure 1) proposed product categories (commodity, quasi-commodity, look-and-feel goods, and look-and-feel goods with variable quality) on the Web by considering how the product's attributes are (not) easily evaluated by customers. Cho \& $\mathrm{Ha}(2003)$ also noted that products on the Web are unequal due to the inability to deliver actual services or to adequately detail the specific nature of products.

It seems that such product classification plays an important role for the management and success of ebusinesses. In fact, in the early stage of e-business, businesses that sold a product category, identified as "quasicommodity products" by Figueiredo (2000) including books and computers, seemed to be popular and have a higher level of user acceptance due to such reasons as quality being relatively and easily evaluated via Web. However, ebusinesses that sell "look-and-feel" goods that need to be seen/tried on/smelled/touched have been paid less attention. Therefore, applying e-strategies that minimize risk and uncertainty has been a significantly important factor for the success of e-businesses.

\footnotetext{
${ }^{1}$ The term "look-and-feel" product with various qualities proposed by Figueiredo (2000).
} 


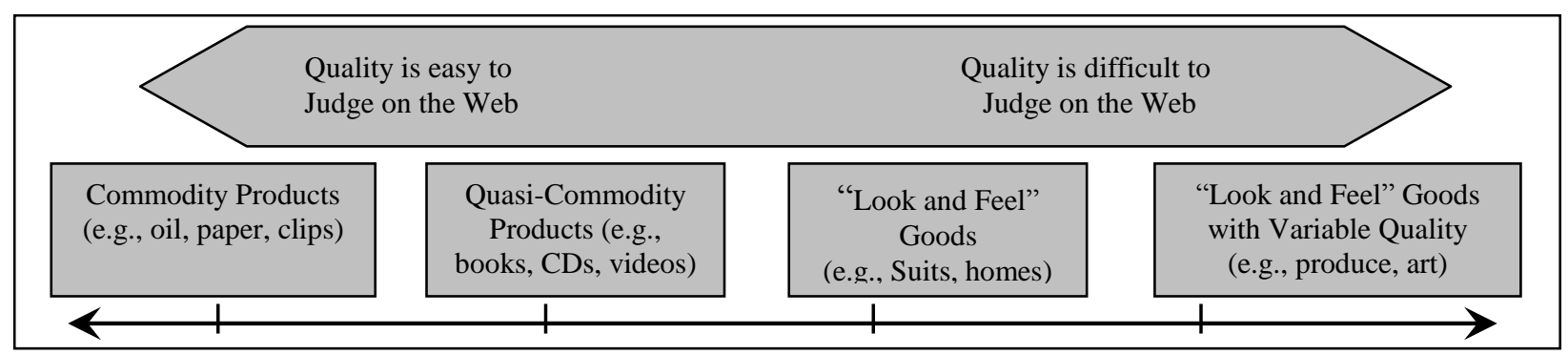

Figure 1. The Dot Come Retail Continuum (Figueiredo 2000)

The author posits that different impacts based on product classification are the result of "telepresence." The current practices of e-commerce have been shaped by the CMC medium responsible for the creation and application of "telepresence." By considering such limitations that take place in the virtual space, the growth of successful applications of "telepresence" in a number of different settings and roles, suggests that the traditional economic activities are undergoing a profound transformation. But practical examples also show us that efforts to build a "telepresent" economy are not all successful in terms of user acceptance and business profits. This has raised the managerial question of being able to predict and plan for success rather than failure, taking the advantage of telepresence to places where it can build a competitive advantage and user value, thus proving to be a sound business effort. This takes the view that current CMC techniques applied to e-commerce have outgrown the different application domains where the needs and benefits sought may have been different from what is required for successful business applications.

By considering the development of e-commerce and sustaining competitive advantage, substantial profits will be found with product categories that had less attention paid to them (Figueiredo 2000; Figure 2). Such categories are named "look-and-feel" or "look-and-feel with variable quality" products as the quality of goods are not easily determined on the Web. However, as e-commerce has developed, there are many opportunities to attract customers depending on the types of strategies that businesses adopt. In fact, many businesses that sell look-and-feel products such as clothes successfully caught and managed customer attention by applying advanced strategies (e.g., www.landsend.com). Online businesses that utilize multi-retail formats (e.g., online with catalogue businesses) also successfully approach customers and win in a competitive market environment (e.g., www.victoriassecrets.com). By keeping pace with this development and by expanding niche markets, this study posits that online grocers have opportunities to enhance customer attention.

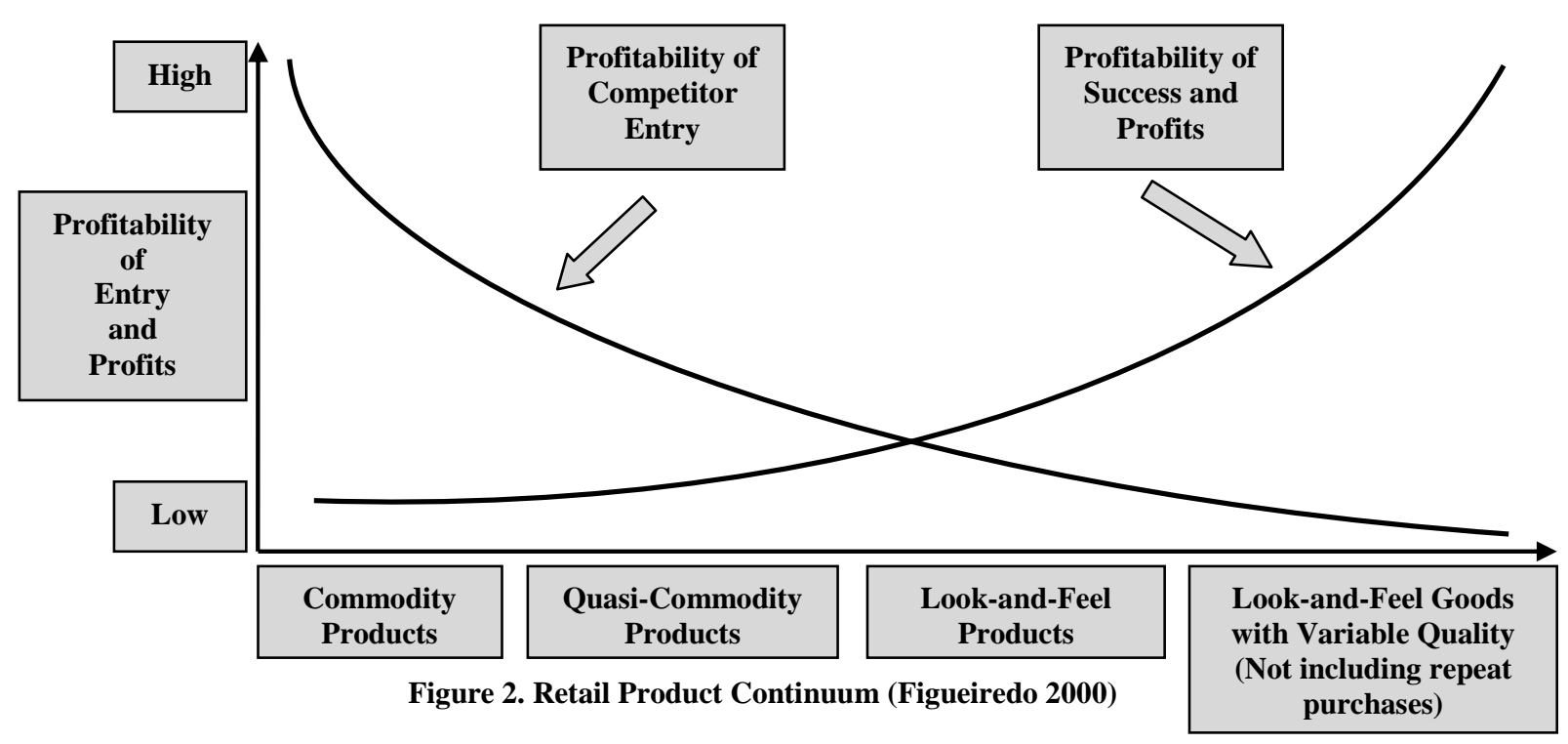


The motivation of this research is the belief that factors which affect customer attitudes/expectations toward online grocery stores also affect the current and future development of e-commerce. Particularly, this study measures opinions from customers who had never used online grocery store. The author of this paper posits how ebusinesses that might lead the future success change customer attitudes and buying behavior. Various concerns exist in changing customer buying behavior as related to the attitudes toward online grocery shopping behavior. Besides the factor how quality is easily determined on the web, other factors that affect consideration of changing buying behavior toward grocery shopping include: 1) a family member who is in charge of grocery shopping, 2) single vs. married customers, 3) the number of family members, and 4) personal characteristics (e.g., value seekers ${ }^{2}$, passive shoppers $^{3}$, etc.). Numerous online grocers have encountered difficulties due to a consideration of customer behavioral changes, positioning, target markets, delivery-related issues, maintaining freshness, etc. Some online grocers have survived with the support of giant offline grocers and/or finding out unique positions (e.g., selling nonperishable items only). Although there is considerable research on the topic of e-commerce, not many studies have explored issues on customer attitudes toward online grocery stores. This paper examined the following issues: 1) the factors affecting user attitudes toward online grocery stores, 2) how those factors affect perceived ease of use (EOU) and usefulness (U), and 3) the effects of perceived ease of use (EOU) and usefulness (U) on overall customer satisfaction toward online grocery stores.

\section{HYPOTHESES DEVELOPMENT}

A previous study (Hallowell 2002) raised the issue of how the different forms of services are conducted through the Internet, "virtual" (either pure information or automated and also called "pure-play") and/or "physical" (requiring some degree of human intervention). Such idea is related to Figueiredo's (2000) proposition, the "dot com retail continuum," based on the idea of how easy or difficult quality is to be delivered on the Web without physical assistance or experiences. Cho \& Ha (2003) also mentioned that customer behavior and the level of satisfaction are based on the product classification, sensory and non-sensory product ${ }^{4}$, cost, time effort, and ego involvement. The author posits that how customers perceive the products and their ability to determine quality on the Web have changed as customers' experiences and comparison analysis skills with online shopping that affect purchase decisions have enhanced. As with the development of technology and its applications, concerns with inherent limitation of e-businesses, i.e., product's sensory attributes such as touch and smell are not conveyed through senses (Degeratu et al. 2000, Cho \& Ha 2003), seem to be reduced.

In order to switch customer behavior and maximize customer satisfaction regarding online grocery businesses, this study suggests that those businesses should provide higher levels of value-added services (VAS) within an integrated advanced technology system such as recommended services, one-to-one service, alarm systems based on previous shopping history, offering customized recipes, etc. According to Terry Drayton, CEO of Homegrocer, what makes the business unique is that it turns the traditional e-commerce business model on its head (Huff \& Beckow 1988). A business example, www.webvan.com claimed that its prices were cheaper, provided hand-delivery system in a timely manner and monitored quality (Taylor 2003). Another, www.netgrocer.com addressed convenience, simplicity, and superior fit with consumer lifestyle (Taylor 2003). Www.le-shop.ch targeted busy households, particularly families who were looking for ways to free themselves from stressful household replenishment duties, but for whom excellent product quality was an absolute must (Taylor 2003).

The current savvy online customers' expectations of technology have been increasing. Most of customers are already experienced on online and online shopping except the late laggard. Hybrid services that are applied to multi-retail formats and communication systems such as combined services of e- and m-commerce are also widely

\footnotetext{
${ }^{2}$ Value seekers are defined as a group that expect value for money and tend to be younger people who shopped around to compare deals (Taylor 2003).

${ }^{3}$ Passive shoppers are defined as a segment that is generally excited about technology but not really interested in grocery shopping (Taylor 2003).

${ }^{4}$ Sensory products were defined as those that have attributes that can be conveyed through our senses, particularly touch, smell, or sound, while non-sensory products were defined as products with attributes that can be conveyed reasonably well in words (Degeratu et al. 2000).
} 
utilized to meet customers' higher level of needs and wants. Such applications could successfully approach the customers, and usability and customized applications such as recommender systems should be also considered and adopted. Prior studies have discussed how perceived usefulness and ease of use are influenced by various factors, including the system's technical design characteristics (Benbasat \& Dexter 1986; Dickson, DeSanctis, \& McBride 1986; Malone 1981). Technology factors include website effectiveness - speed and customer interface design factors (Mohammed, Fisher, Jaworski, \& Cahill, 2002) such as content, context, and customization. Technology and mediainherent factors, proposed by Schubert and Dettling (2002), are applied in this study of e-commerce. This study posits such factors that are related to the technology will be also applied to e-commerce environments. This study hypothesized that customer perception of the technology factor of online grocery market is positively associated with perceived usefulness and perceived ease of use.

This study proposes that e-business should apply e-marketing strategies and theories. Uses and gratification theory (Herzog 1944; McGuire 1974; Luo 2002) has been applied in this study to explain users' attitudes and user satisfaction toward e-commerce usages. Well-known satisfaction theories that have explained consumer attitudes to brick-and-mortar businesses, such as contrast theory (Engel and Blackwell 1982; Cardozo 1965) and dissonance theory (Festinger 1957), have been applied in this study of e-commerce/businesses. Uses and gratification theory has been developed from research in the context of traditional media, such as TV, magazines, or radio (Herzog 1944; McGuire 1974). It has been extended to research in the context of the online environment (e.g., Luo 2002). The present study has been supported by another theory, the Theory of Reasoned Action (TRA), which suggests that individuals' performance of a given behavior is primarily determined by their intention to perform that behavior (Ajzen and Fishbein, 1980). This study adopted the Technology Acceptance Model, which has been widely used in the research of online user behavior, to describe users'/customers' attitudes and behavior in the e-commerce environment. The author in this paper expects that the model explains online customers' willingness to adopt business and how their internal beliefs and attitudes affect their satisfaction (Davis 1989; DeSantics 1983; Ives, Olson, and Baroudi 1983). Diffusion of innovation theory (Rogers 1995) also have applied to explain the customer behavior that customers adopt new technology by considering factors, such as innovation, over time, communication through certain channels, and among the members of a social system.

The theory also has applied a previous study (Carlsson, Hyvonen, Repo, and Walden 2005) to explain the features of users and the features of technological innovations for e-businesses. Therefore, within the uses and gratification theory framework and TRA, this study explored factors that affect perceived Usefulness (U) and Ease of Use (EOU) for online grocery businesses. In particular, this study classifies factors that can be used to measure perceived $\mathrm{U}$ and EOU. As show in Figure 3, the proposed model of this study is determined by the different factors that trigger perceived usefulness and ease of use and e-satisfaction.

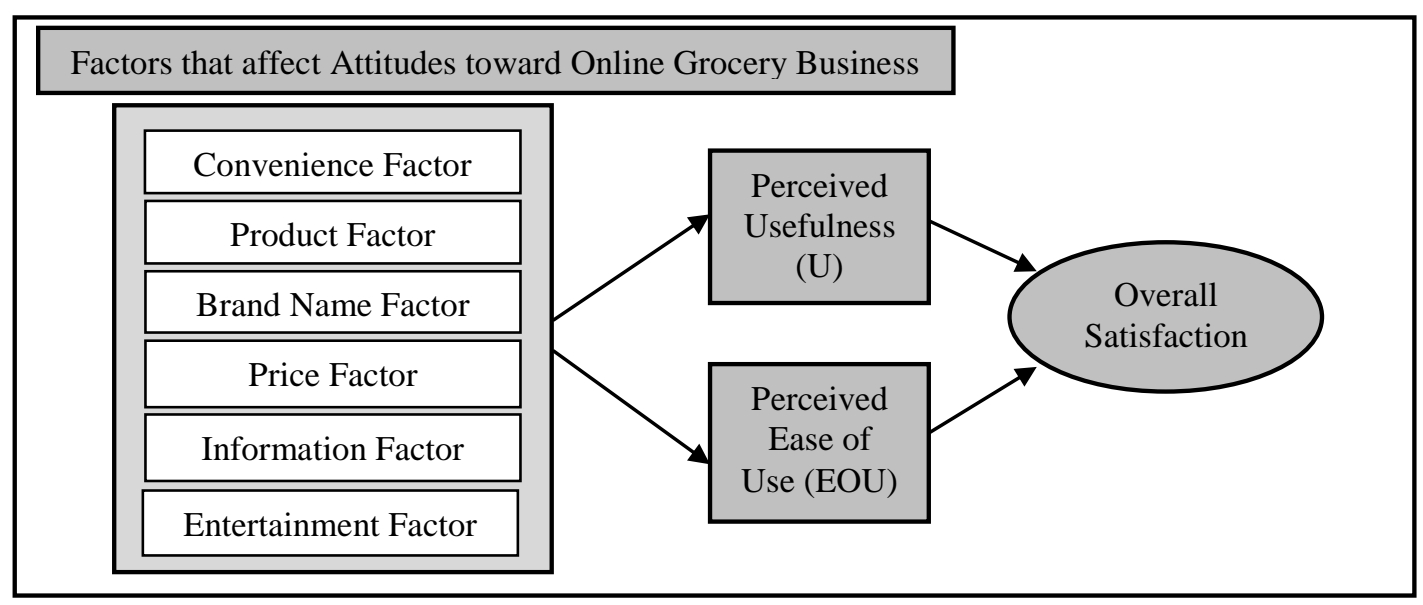

Figure 3. The Proposed Model of Customers' Attitudes/Expectations toward Online Grocery Business \& E-Satisfaction 
Factors proposed in this study include convenience, product, brand name, price, information, and entertainment factor (Figure 3). This study measures the impact of such factors on perceived usefulness and ease of use. The study also measures how user attitudes toward online grocery business are affected by perceived usefulness and ease of use. In this study, perceived usefulness and ease of use are considered predictors to investigate the selected variables that affect customers' acceptance of online grocery shopping behavior. This study also measures how perceived usefulness and ease of use toward online grocery business affect overall customer satisfaction.

H1a: As perceived usefulness (U) on online grocery business is higher, positive customer satisfaction toward online grocery business increases.

H1b: As perceived ease of use (EOU) on online grocery business is higher, positive customer satisfaction toward online grocery business increases.

\subsection{Attitudes/Expectations toward Online Grocery Business and E-Satisfaction}

Attitudes toward online business have been often considered a variable to measure the effectiveness of system (e.g., Zhou 2002; Chen and Wells 1999). Opportunities for online grocery market have been addressed by various researches. Pastore (2000) cited that the online grocery market is taking a growth path that no other ecommerce business has trod. According to a study by datamonitor, the online grocery market is experiencing rapid growth due to growing Internet penetration, entry of new players, and the realization amongst time-pressured consumers of the convenience of online purchasing (www.datamonitor.com/consumer). As estimated by Forrester Research (www.emarketer.com), online grocery sales have grown (will be grown) from \$6.2 (2007) to \$13.7 (2012). Even though customer attitudes toward online grocery stores do not seem to be active, there seem to be opportunity to change customer attitudes toward the online grocery business more active. It is also expected that customers' preferred product category on the Web is also changed from commodity to look-and-feel goods with the development of the e-commerce. This study posits that customer attitudes and behavior on online grocery markets are based on how customers perceive such businesses. Assuming that online grocery markets provide equivalent services that can be found in the offline markets (i.e., store-based markets) or even more valuable services, there are lots of potentials for online grocery markets to grow even faster. Opportunities to change grocery shopping habits from offline to online also exist as current customers are very much experienced with e-transaction and pursue better values.

This study posits that attitudes/expectations toward online grocery businesses should be discussed to measure the building a relationship with a business, customer loyalty, and e-satisfaction. Satisfaction or dissatisfaction theories, such as cognitive dissonance theory (Festinger, 1957), contrast theory (Engel and Blackwell, 1982; Howard and Sheth, 1969; Cardozo, 1965), and adaptation level theory (Helson, 1964) have been applied in this study to measure e-satisfaction. The traditional market places emphasized on "user and customer satisfaction" as a way to earn consumer loyalty and attract new customers. Previous studies (Cho and Fjermstad 2005) have examined the firm's approach to Customer Relationship Management (CRM) in order to account for the new realities of market spaces. Previous studies (Cho, Im, Hiltz, and Fjermestad 2001) have posited that maximizing customer satisfaction and maintaining customer loyalty are major components for Electronic - Commerce Customer Relationship Management (ECCRM). It is hypothesized that positive attitudes toward online grocery business increase overall satisfaction.

\subsection{Convenience Factor}

Various researchers found that a major factor in increasing consumer satisfaction from e-commerce is convenience (Cho, Im, Hiltz, \& Fjermestad 2001). How e-business offers convenience and how customers perceive it significantly affect customer attitudes toward online grocery market. Expected target customer groups that prefer online grocery market include time-pressured consumers such as busy professionals and working parents with a child (or children), customers who perceive grocery shopping as a hassle, customers who had not taken the role of purchasing grocery items previously, but now take the role, and customers whose poor health prevent them from going to an offline market, etc. In considering target markets, convenience is the key attraction for time-pressured consumers to shop online (www.datamonitor.com). Offline grocery shoppers have experienced various inconveniences, such as carrying heavy items, parking, waiting at the check-out counter, etc. As with the perception 
of e-businesses as providing convenience, through efficient systems (e.g., comparison analysis system) and advanced valuable services, customers will more likely perceive online grocery markets as a convenient retail space.

As the online business has developed, customers' expectations of convenient and value-added services have increased. In addition to the basic services that are provided by most online stores, value-added services that enhance customers' satisfaction and minimize complaints should be adopted. For example, value-added services such as higher levels of customization including reminder service, keeping purchasing history, analyzing preferred products/brands, and suggestions of recipes and cooking methods will enhance customer attention. More services should be made available based on the development of technology. Combined services with mobile phones to introduce new products that customers had searched for and to provide advanced services are also suggested. This study hypothesizes that user perception of the convenience of online grocery market positively affects perceived usefulness and ease of use.

H2a: As users' perception of the convenience of online grocery market increases, perceived usefulness increases. H2b: As users' perception of the convenience of online grocery market increases, perceived ease of use increases.

\subsection{Product Factor}

Product availability has been an important factor that affects customer attitudes and satisfaction. In order to meet customers' needs, online grocery markets should consider the product assortment, variety, and differentiation that are often applied to offline product strategies. As mentioned by Linn (2007), while online is very convenient and has a lot of offer, there are certain things customers want from the store. Although online stores offer various products/services, product availability should be significantly more considered for online grocery markets as customers' products/brands choice varies. In addition to the product variety, consideration and maintenance of product quality should be the key for the online grocery business. Based on the consideration of product-related issues, this study hypothesizes that user perception of the product/service quality toward online grocery markets positively affects perceived usefulness and ease of use.

H3a: As customers' perception of the products provided by online grocery markets is higher, perceived usefulness increases.

H3b: As customers' perception of the products provided by online grocery markets is higher, perceived ease of use increases.

\subsection{Brand Name Factor}

Brands help buyers recognize certain products that they like and dislike and also facilitate the purchase of items that satisfy their needs and reduce the time required purchasing the product (Pride \& Ferrell, 2003). The role of brands has been frequently addressed in previous studies. Traditionally, brand names serve a variety of purposes for consumers and advertisers (Meyers-Levy 1989). Various researchers (e.g., Meyers-Levy 1989) have noted that firms with extremely memorable brand names often regard those names as their most valuable asset because these labels provide immediate recognition, and often, acceptance of new products that may be introduced under the brand name.

Previous studies found impacts of brand awareness and familiarity on product category (Cho 2007). According to Baker and Nedungadi (1986), consumers think of the brand when they think about the product category, and raising brand awareness increases the likelihood of that the brand being a member of the consideration set. This study posits how customers perceive brand names significantly affect customer attitudes toward online grocery markets. In particular, online grocery markets sell perishable items that are the most risky and uncertain in the buyers' perspective as the quality is not easily determined on the Web: therefore building brand reliability is a major concern. The development of brand reliability should be even harder for "pure plays" (i.e., pure online businesses) than for extended offline retail store, for customers have built perceptions about the store in their mind. This study hypothesizes that user perception of the brand name of online grocery market positively affects perceived usefulness and ease of use. 
H4a: As users' perception of the brand name of online grocery market increases, perceived usefulness increases.

H4b: As users' perception of the brand name of online grocery market increases, perceived ease of use increases.

\subsection{Price Factor}

Price plays a large role in the choice and quantity of decisions (Krishnamurthi \& Raj 1988). Previous researchers have stated that price is a major factor in measuring consumer sensitivity (Krishnamurthi \& Raj 1988). Hanson (2000) posited that the Internet will raise or lower price sensitivity among customers. Customers' perception on the price offered by online businesses are lower due to the direct marketing operated with an efficient channel system. Therefore, like other forms of online shopping, the future of the grocery market is likely to come down to convenience and price (http://www.clickz.com). A study (http://www.clickz.com) stated that online grocers should offer competitive prices as not many customers are willing to pay more for products and/or services with online grocery businesses. According to the PricewaterhouseCoopers survey (http://www.clickz.com), price remains a key driver of online shopping behavior in the grocery category. The consideration of lowered price is important in making customers that they are actually saving time and money and enjoying convenient services.

Some customers might prefer offline grocery markets as they are more accustomed to offline promotions, such as coupons, rebates, and the discounts offered to retail store card holders, etc. However, such promotional tools that trigger customer attention are (or could be) applied to online grocery markets. Hybrid retail stores of online and offline apply such promotional tools and pricing strategies differently or alternatively to target different customer segments. By applying more integrated marketing communication tools such as partnership and push strategies (i.e., it allows companies to push a message to consumers rather than waiting for them to find it: Belch \& Belch 2007), customers' positive attitudes toward online grocery stores will be enhanced. Therefore, this study posits that utilizing promotions that help purchase decision and increase customer satisfaction will significantly affect attitudes toward the online grocery market. This study hypothesized that customer perception of price factors of online grocery markets is positively associated with perceived usefulness and perceived ease of use.

H5a: As users' perception of the price offered by online grocery market is higher, perceived usefulness increases. H5b: As users' perception of the price offered by online grocery market is higher, perceived ease of use increases.

\subsection{Information Factor}

How the online business provides detailed information has greatly affected to the purchase decision. One of the reasons for the early success of online businesses that sell commodity and quasi-commodity products is that product information is easier to deliver over the Web. Degeratu, Rangaswamy, and Wu (2000) pointed out that information availability affects consumers' decision making and it differs in the online and offline environments. Dick et al. (1990) also noted that consumers focus on relevant attributes that are available and are diagnostic when they search for information in the online context. In order to successfully approach customers, this study suggests that online grocery businesses should apply more advanced services by providing detailed information to minimize uncertainty. Moreover, it will positively affect users' behavioral intention to use (Cho 2008). Therefore, this study hypothesized that how customers perceive information quality offered by online grocery markets affect perception of ease of use and usefulness.

H6a: As users' perception of the information quality provided by online grocery market increases, perceived usefulness increases.

H6b: As users' perception of the information quality provided by online grocery market increases, perceived ease of use increases.

\subsection{Entertainment Factor}

Even though online businesses provide convenience, various products, and value added services, how customers perceive online grocery markets rely on how they perceive it as fun activity. Even though the quality of look-and-feel goods is not easy judge on the Web, the degree varies based on various factors such as personal characteristics and sensitivity to risk and uncertainty. Customer attitudes toward online grocery markets are also 
affected by other factors such as word-of-mouth effects (e.g., how likely a customer tends to follow other person's behavior). As online businesses have the advantage of utilizing viral marketing which is a form of word-of-mouth, customers' tendencies toward word-of-mouth affect online purchasing behavior. How customers perceive online or offline shopping - as fun or stressful activity - might affect overall attitudes toward the online grocery markets. Such customer attitudes are also explained by the social escapism motivation theory which explains consumers' motives for using the Web as a reliever of day-to-day boredom and stress (Zhou 2002: Korgaonkar \& Wolin 1999). This study posits that customers' positive perception of online grocery markets, as a more fun and entertaining activity will affect overall attitudes. This study hypothesizes that customers' perception of online grocery market positively affects perceived usefulness and ease of use.

H7a: As customers' perception of online grocery shopping as an entertaining activity is higher, perceived usefulness increases.

H7b: As customers' perception of online grocery shopping as an entertaining activity is higher, perceived ease of use increases.

\section{METHODOLOGY}

\subsection{Data Collection}

Among e-businesses, this study measures customer expectations toward the online grocery markets. This study conducted surveys with about two hundred forty randomly selected subjects who have attitudes/expectations about online grocery markets. The data were collected both from convenience samples (i.e., samples selected from Information Systems (IS) and the management departments at two major universities in the U.S.) and from online surveys. The response rate was about $74 \%$ from offline and $47 \%$ from online. Approximately $84 \%$ of the respondents answered that they had never used online grocery store. Among the $16 \%{ }^{5}$ of the respondents who answered that they had used an online grocery store, approximately $92.3 \%$ answered that they had started using the online grocery store less than one year ago and $84.6 \%$ order products from online grocery stores once per month (while $15.4 \%$ twice per month). While the usage rate of the online grocery store seems low, the level of satisfaction was about $61 \%$, including "somewhat satisfied" (23.1\%), "satisfied" (23.1\%), and "strongly satisfied" (15.4\%).

\subsection{Operational Measures}

Multi-item scales were used to measure each of the seven constructs that served as the basis for the questionnaire items. The item scales were taken from previous studies (e.g., Davis 1989; Davis, Bagozzi, and Warshaw 1989; Bearden and Teel 1980; Fishbein and Ajzen 1975) ${ }^{6}$ and modified to serve the objectives of the present study. Quantitative methods, including factor analysis, regression, and ANOVA (Analysis of Variance), were applied to measure perceived usefulness, perceived ease of use, online customers' attitudes toward the business, and e-satisfaction. This study measured whether factors such as "convenience factor," "product factor," "brand name factor," "price factor," "information factor," and "entertainment factor" affect perceived usefulness and ease of use toward online grocery markets. The scales in this study were developed from previous studies: for example, scales for perceived usefulness and perceived ease of use were from the study by Davis (1989) and Davis, Bagozzi, and Warshaw (1989). Scales for other variables were from studies by Succi and Walter (1999), Zhou (2002), Schubert and Selz (1999), and Chen and Wells (1999). Likert scales, semantic differential scales, and openended questions were used to measure the items. For Likert scale questions, a seven-point scale was used with extremes labeled such as "Strongly Disagree" and "Strongly Agree" was used.

\footnotetext{
${ }^{5}$ As stated earlier, this study measured impacts based on respondents who had never used online grocery store (i.e., $84 \%$ of respondents that is about two hundred two)

${ }^{6}$ Seven-point $(1=$ strongly dissatisfied, $4=$ Not dissatisfied at all, $7=$ Strongly satisfied $)$ scales were employed.
} 


\section{RESULTS}

\subsection{Respondent demographics}

Of the respondents who had never used online grocery store, $59.5 \%$ were female and $40.5 \%$ were male. About $23.3 \%$ were between the ages of $18-20 ; 68.5 \%$ were between the ages of $21-30 ; 5.5 \%$ were ages $31-35$; and $2.7 \%$ were 36 or older. Approximately $26.0 \%$ reported that their highest educational level was high school graduate, $35.6 \%$ had an associate degree, and $38.4 \%$ were still studying at a university for an undergraduate degree. About $15.5 \%$ were white American, $16.9 \%$ were Asian American, $1.4 \%$ were Hawaiian, $7.0 \%$ were Hispanic, $1.4 \%$ were Middle Eastern, $38 \%$ were Asian, and $18.3 \%$ were European. In order to check construct reliability, this study measured Cronbach's alpha for multi-item scales to measure each of the six constructs that served as the basis for the questionnaire items. This study found that Cronbach's alpha for the convenience factor showed $0.85 \%$; for product, $0.77 \%$; brand name, $0.76 \%$; price, $0.80 \%$; information, $0.74 \%$; entertainment, $0.73 \%$; and perceived ease of use and usefulness, $0.92 \%$.

\subsection{Hypotheses Testing}

Table 1. Component Matrix

\begin{tabular}{|c|c|c|c|c|c|c|c|}
\hline \multicolumn{2}{|r|}{ Items } & \multicolumn{6}{|c|}{ Component } \\
\hline External Factors & Scale Items & 1 & 2 & 3 & 4 & 5 & 6 \\
\hline CONVENICENCE II & $\begin{array}{l}\text { It is (would be) easier to find grocery items that I } \\
\text { wish to buy from online. }\end{array}$ & .822 & & & & & \\
\hline CONVENICENCE V & $\begin{array}{l}\text { Online grocery shopping is (would be) convenient } \\
\text { as I can easily access it } 24 \text { hours/7days. }\end{array}$ & .802 & & & & & \\
\hline CONVENICENCE III & $\begin{array}{l}\text { It is (would be) convenient if ordered items are } \\
\text { (will be) delivered to home. }\end{array}$ & .754 & & & & & \\
\hline CONVENICENCE IV & $\begin{array}{l}\text { It would be convenient if online grocery business } \\
\text { provides me a customized service (e.g., alarm me } \\
\text { to order items that I need to order). }\end{array}$ & 669 & & & & & \\
\hline PRICE III & $\begin{array}{l}\text { I (am willing to) purchase products from online } \\
\text { grocery market more if it offers discounts } \\
\text { regularly. }\end{array}$ & & .814 & & & & \\
\hline PRICE V & $\begin{array}{l}\text { I (might) prefer to order items from online } \\
\text { grocery markets as prices are easily compared. }\end{array}$ & & .698 & & & & \\
\hline BRAND NAME I & $\begin{array}{l}\text { I often (am willing to) select the online grocery } \\
\text { store that I am familiar with. }\end{array}$ & & & .843 & & & \\
\hline BRAND NAME III & Familiar grocery store brands are more reliable. & & & .764 & & & \\
\hline BRAND NAME II & $\begin{array}{l}\text { Brand image of offline grocery store affects the } \\
\text { selection of online store. }\end{array}$ & & & .712 & & & \\
\hline ENTERTAINMENT IV & $\begin{array}{l}\text { It is (would be) fun to use online grocery } \\
\text { shopping. }\end{array}$ & & & & .854 & & \\
\hline ENTERTAINMENT V & $\begin{array}{l}\text { Online grocery shopping (will) provide(s) me } \\
\text { pleasure. }\end{array}$ & & & & .753 & & \\
\hline ENTERTAINMENT III & $\begin{array}{l}\text { It (would be) is fun to receive promotional } \\
\text { messages (e.g., discount) from online grocery } \\
\text { store. }\end{array}$ & & & & .725 & & \\
\hline INFORMATION IV & $\begin{array}{l}\text { I am satisfied with the information quality } \\
\text { provided by online grocery markets. }\end{array}$ & & & & & .830 & \\
\hline INFORMATION II & $\begin{array}{l}\text { I often use online grocery store for information } \\
\text { purpose only. }\end{array}$ & & & & & .750 & \\
\hline INFORMATION I & $\begin{array}{l}\text { Online grocery markets provide better } \\
\text { information. }\end{array}$ & & & & & .747 & \\
\hline PRODUCT I & $\begin{array}{l}\text { If products are varied, I am willing to use online } \\
\text { grocery store more. }\end{array}$ & & & & & & .665 \\
\hline PRODUCT II & $\begin{array}{l}\text { I expect that I can easily find alternative products } \\
\text { from online grocery shopping. }\end{array}$ & & & & & & .614 \\
\hline \multicolumn{2}{|l|}{ Eigen Value } & 2.439 & 1.926 & 1.549 & 1.373 & 1.284 & 1.222 \\
\hline
\end{tabular}


The first step in this analysis was intended to validate the factors that affect two predictors: perceived usefulness and ease of use. This study ran a confirmatory factor analysis to identify those factors. Using principal components analyses as the extraction method and Varimax rotation methods with Kaiser Normalization, the most relevant data emerged. These analyses showed a distinct reduction of six factors, with Eigen values over 1.00. Six factors that affect perceived usefulness and ease of use toward online grocery businesses appeared to be "convenience factor," "product factor," "Brand name factor," "price factor," "information factor," "and "entertainment factor (Table 1)." Separate factor analysis were done to group scale items for the predictors, perceived usefulness (U) and ease of use (EOU) that affect overall satisfaction. Scale items were developed from the previous study by Davis (1989). Three items represent both perceived usefulness and ease of use.

This study analyzed simple linear regression analyses and the analyses of variance (ANOVA). Factor scores were used for regression analyses. This study used regression analyses for the impacts of variables to the dependent variables that are perceived usefulness and ease of use. Another regression analysis was conducted to examine the effects of perceived usefulness and ease of use to overall expected customer satisfaction. Table 2 presents the results of the regression analyses for the effects of variables to the perceived usefulness (U) and ease of use (EOU). Stepwise regression analysis was applied to determine how indicators affect perceived usefulness and ease of use. The results in Table 2 show that factors, such as convenience, price, entertainment, information, and product factors, affect perceived usefulness, while factors, such as convenience, brand name, entertainment, information, and product factors, affect perceived ease of use. Thus, hypotheses $2 \mathrm{a}-7 \mathrm{a}$ excluding $3 \mathrm{a}$ were accepted while hypotheses $2 b-7 b$ excluding $2 b$ were accepted. The results of the analysis of variance found the models significant at the .01 level with $F=13.315$ (two-tailed, $r$-square $=.646$ ) for perceived usefulness and $F=3.473$ (two-tailed, $r$-square $=.423$ ) for ease of use.

Table 2. The Effects of Variables on the Perceived Usefulness (U) and Perceived Easy of Use (EOU)

\begin{tabular}{|l|l|l|}
\hline \multirow{2}{*}{ Variable } & \multicolumn{2}{c|}{ Standardized Coefficient (Sig- $\boldsymbol{t}$-value) } \\
\cline { 2 - 3 } & $\mathbf{U}$ & EOU \\
\hline Convenience factor & $.001\left(3.664^{* * *}\right)$ & $.095\left(1.754^{*}\right)$ \\
\hline Price factor & $.000\left(6.244^{* * *)}\right.$ & $.565(.580)$ \\
\hline Brand Name factor & $.234(1.204)$ & $.001\left(3.615^{* * *}\right)$ \\
\hline Entertainment factor & $.002\left(3.293^{* * *)}\right.$ & $.093\left(1.769^{*}\right)$ \\
\hline Information factor & $.030\left(2.237^{* *}\right)$ & $.003\left(3.021^{* * *}\right)$ \\
\hline Product factor & $.001\left(3.558^{* * *}\right)$ & $.063(1.901 *)$ \\
\hline
\end{tabular}

*** Significant at 0.01 level (2-tailed); ** Significant at 0.05 level (2-tailed); * Significant at 0.1 level (2-tailed)

Another regression analysis was conducted to see how overall expected satisfaction toward online grocery store is affected by perceived usefulness and ease of use. Table 3 shows the results of regression analysis for the impact of $\mathrm{U}$ and EOU on the expected customer satisfaction. The results of an analysis of variance found that overall, the regression model was significant $(F=51.818$, significant at the .01 level, two-tailed, $r$-square $=.622$ ). Therefore, hypotheses 1 a \& b were accepted.

Table 3. The Effects of Predictors on the Overall Satisfaction

\begin{tabular}{|l|c|}
\hline \multicolumn{1}{|c|}{ Predictors } & Standardized Coefficient (Sig- $\boldsymbol{t}$-value) \\
\hline Perceived Usefulness & $.000\left(8.677^{* *}\right)$ \\
\hline Perceived Ease of Use & $.000\left(5.325^{* * *}\right)$ \\
\hline
\end{tabular}

*** Significant at 0.01 level (2-tailed) 


\section{DISCUSSION AND CONCLUSION}

This research paper explored customers' attitudes toward online grocery store and e-satisfaction. The findings of the study contribute to the development of the uses and gratification theory and Technology Acceptance Model, while also providing implications and suggestions for e-businesses. Applying various theories and models, this study investigated which factors affect the attitudes toward online grocery store, how those factors affect perceived usefulness and ease of use, the effects of perceived ease of use, and usefulness to overall customer satisfaction. This study found important factors that affect consumer attitudes/expectations toward online grocery businesses: 1) factors such as convenience, entertainment, information, and product significantly affect both perceived usefulness and ease of use; 2) brand name factor significantly affects ease of use and price factor significantly affect usefulness; and 3) both perceived usefulness and ease of use significantly affect overall satisfaction.

Furthermore, this study provides implications and offers suggestions for e-businesses development and user acceptance. This study suggests that there are opportunities for the online grocery business. By considering the late acceptance and usage of the online grocery businesses, various e-marketing applications could be utilized to grasp customer attention and acceptance. This study posits that by changing customers' perceptions and identifying the right target markets, online grocery businesses will turn to more profitable position. In addition to the existing strategies that have been applied to e-business, advanced value-added strategies such as technologies that deliver smells via the web that appeal to customers in overcoming the inherent limitation of the online grocery business should be applied to maximize customer satisfaction. The author believes that more applications and usages will lead to higher customer satisfaction and loyalty toward e-commerce customer relationship management.

The study has some limitations. Although this study used multivariate statistics, such as factor and regression analysis, the study did not measure the cause and effect relationship using a program, such as LISREL. The researchers will consider this issue in future research. For future studies, researchers will also investigate causes that affect different impacts toward online grocery business and also cross-cultures/countries. For further studies, a larger number of subjects will be surveyed.

\section{AUTHOR INFORMATION}

Dr. Yoon C. Cho is Associate Professor at the KDI School Of Public Policy And Management, global school, located in Seoul. Previously, she was Associate Professor at Hawaii Pacific University, where she served as advisor of the American Marketing Association (AMA) - HPU Chapter. She received Ph.D. from Rutgers, The State University of New Jersey and MBA from Cornell University. She published research papers in the various academic journals such as Advances in Consumer Research (ACR), Journal of Consumer Satisfaction, Dissatisfaction, and Complaining Behavior (JCS/DCB), Hawaii International Conference on System Sciences, Journal of Business \& Economics Research, etc. Email address: ycho@kdischool.ac.kr

\section{REFERENCES}

1. Ajzen, I. and Fishbein, M. (1980). Understanding Attitudes and Predicting Social Behavior. Englewood Cliffs, NJ, Prentice-Hall.

2. $\quad$ Baker, W. J., Nedungadi, P. (1986) "Brand Familiarity and Advertising: Effects on the Evoked Set and Brand Preferences," Advances in Consumer Research, 13. Richard J. Lutz, ed. Provo, UT: Association for Consumer Research.

3. Belch, George E. and Belch, Michael A. (2007), Advertising and Promotion: An Integrated Marketing Communications Perspective, McGraw-Hill Irwin.

4. Benbasat, I. And Dexter, A. S. (1986). An Investigation of the Effectiveness of Color and Graphical Presentation under Varying Time Constraints, MIS Quarterly, March, 59-84.

5. Cardozo, R. N. (1965). An Experimental Study of Customer Effort, Expectation, and Satisfaction. Journal of Marketing Research, 2, August, 244-49. 
6. Carlsson, Christer, Hyvonen, Kaarina, Repo, Petteri, and Walden, Pirkko (2005), “Asynchronous Adoption Patterns of Mobile Services," Proceedings of the $38^{\text {th }}$ Hawaii International Conference on System Sciences, January.

7. Chen, Q. and Wells, W. D. (1999). Attitudes Toward the Site. Journal of Advertising Research, September/October, 27-37.

8. Cho, Y. (2008), "Effects of Social Networking Sites (SNSs) on Hyper Media Computer Mediated Environments (HCMEs)," The International Business \& Economics Research Journal (IBER). Vol 7, Issue 7, pp. 27-40.

9. Cho, Y (2007), "Measuring Customer Attitudes toward Single vs. Hybrid Retail Formats: Impact of Gender and Brand Name Familiarity," The Journal of Applied Business Research (JABR), Vol. 23, No. 4, Fourth Quarter, pp. $79-92$.

10. Cho, Y. and Ha, J. (2003), "Consumer Choice Behavior On the Web: The Effects of Product Attributes on Willingness to Purchase," The Journal of Business \& Economics Research, Vol 10. October, pp.75-87.

11. Cho, Y., Im, I., Hiltz, S. \& Fjermestad, J. (2001), The Effects of Post-Purchase Evaluation Factors on Online vs. Offline Customer Complaining Behavior: Implications for Customer Loyalty, the Conference of Association for Consumer Research (October, Austin, Texas).

12. Davis, F. D. (1989). Perceived Usefulness, Perceived Ease of Use, and User Acceptance of Information Technology. MIS Quarterly, 13(3), September, 319-340.

13. Degeratu, A. M., Rangaswamy, A., and Wu, J. (2000), "Consumer Choice Behavior in Online and Traditional Supermarkets: The Effects of Brand Name, Price, and other Search Attributes”, eBusiness Research Center Working Paper, Penn State University, http://www.ebrc.psu.edu/

14. DeSantis, G. (1983). Expectancy Theory as an Explanation of Voluntary Use of a Decision Support System. Psychological Reports, 52, 247-260.

15. Dick, A., Chakravarti, D., Biehal, G. (1990), "Memory-based Inferences During Consumer Choice," Journal of Consumer Research, Vol. 17, pp.82-93.

16. Dickson, G. W., DeSanctis, G. and McBride, D. J. (1986). Understanding the Effectiveness of Computer Graphics for Decision Support: A Cumulative Experimental Approach. Communication of ACM, 29, 40-47.

17. Engel, J. F. and Blackwell, R. D. (1982). Consumer Behavior (4 ${ }^{\text {th }}$ ed.). New York, Holt, Rinehart and Winston.

18. Festinger, L. (1957). A Theory of Cognitive Dissonance. Stanford, California: Stanford University Press.

19. Figueiredo, John M. de (2000), "Finding Sustainable Profitability in Electronic Commerce," Sloan Management Review, Summer.

20. Hallowell, Roger (2002), "Service on the Internet: The Effect of Physical Service on Scalability," Harvard Business Review, October.

21. Hanson, Ward (2000), Principles of Internet Marketing, South-Western College Publishing.

22. Helson, H. (1964). Adaptation-Level Theory, New York: Harper \& Row.

23. Herzog, H (1944). What Do We Really Know About Day-Time Serial Listeners?: Radio Research.

24. Huff, Sid L. and Beckow, David (1998), Homegrocer.com, from the Cases in Electronic Commerce, $2^{\text {nd }}$ edition, McGraw-Hill Irwin.

25. Ives, B., Olson, M. H., and Baroudi, Jack J. (1983). The Measurement of User Information Satisfaction. Communications of the ACM, 26(10), 785-793.

26. Korgaonkar, P. K. and Wolin, L. D. (1999). A Multivariate Analysis of Web Usage. Journal of Advertising Research, March/April, 53-68.

27. Krishnamurthi, L. and Raj, S. P. (1988). A Model of Brand Choice and Purchase Quantity Price Sensitivities. Marketing Science, 7(1), Winter, 1-20.

28. Linn, Allison (2007), "Online Shopping Growth to Slow in Next Decade: Despite Convenience, Some Shoppers don't Trust Online Retailing," http://www.msnbc.msn.com/id/20321999/

29. Luo, Xueming (2002), "Uses and Gratifications Theory and E-Consumer Behaviors: A Structural Equation Modeling Study," Journal of Interactive Advertising, Volume 2, Number 2, Spring.

30. Malone, T. W. (1981). Toward a Theory of Intrinsically Motivating Instruction. Cognitive Science, 4, 333369.

31. Mcguire, W. J. (1974). Psychological Motives and Communication Gratification: The Uses of Mass Communications. Jay G. Blumler and Elihu Katz, (eds.), Beverly Hills, CA: Sage Publications. 
32. Meyers-Levy Joan (1989), "The Influence of a Brand Name's Association Set Size and Word Frequency on Brand Memory," Journal of Consumer Research, September, Vol. 16.

33. Mohammed, R. A., Fisher, R. J., Jaworski, B. J., and Cahill, A. M. (2002). Internet Marketing: Building Advantage in a Networked Economy. McGraw-Hill Irwin, Marketspace U.

34. Pastore, Michael (2000), Online Grocery Market Treading New E-Commerce Waters, http://www.clickz.com/363871

35. Rogers, Everett M. (1995), Diffusion of Innovations, $4^{\text {th }}$ ed., New York: The Free Press.

36. Schubert, P. and Dettling, W. (2002). Extended Web Assessment Method (EWAM): Evaluation of ECommerce Applications from the Customers' Viewpoint. Proceedings of the $35^{\text {th }}$ Hawaii International Conference on System Sciences, Hawaii.

37. Schubert, Petra and Dorian Selz (1999), "Web Assessment: Measuring the Effectiveness of Electronic Commerce Sites Going Beyond Traditional Marketing Paradigms," Proceedings of the $32^{\text {nd }}$ Hawaii International Conference on System Sciences.

38. Taylor, Mary Alice (2003), "Online Grocery Retailing: Building the Last Mile to the Customer," Harvard Business Review.

39. Zhou, Zheng (2002). Users' Attitudes Toward Web Advertising: Effects of Internet Motivation and Internet Ability. Advances in Consumer Research, 29, 71-78.

\section{Online Resources:}

www.datamonitor.com/consumer

www.emarketer.com

http://www.clickz.com 
NOTES 